\title{
Biochemical changes during the induction of mineral stress in plants of bell pepper cultivated in fertigation system
}

\author{
Alteraciones bioquímicas durante la inducción de estrés mineral \\ en plantas de pimiento cultivadas en sistema de fertirriego
}

\author{
Marcelo Leonardo ${ }^{1}$, Fernando Broetto ${ }^{2 *}$, Renata Bruna dos Santos Coscolin ${ }^{1}$, Dayanne Fabrício \\ Bressan $^{1}$, José Abramo Marchese ${ }^{3}$, Marco Antonio Castillo Campohermoso ${ }^{4}$, Edilson Ramos Gomes ${ }^{1}$
}

\section{SUMMARY}

The greenhouse production associated with the fertigation management, have established in Brazil as economical alternative for several horticultural species. With this strategy this study had as aim to evaluate possible impacts in the metabolism of plants of bell pepper (Capsicum annиum L.; cv Elisa) in response to the increase of mineral concentration in the soil. During the experiments, the some nutrient concentrations were altered, to obtain high values of electric conductivity (EC) in the soil solution. The EC values commonly observed in the traditional fertigation system were adopted, as control. It was also verified the possibility of reduction of the mineral stress impact by the application of organic matter in the soil. Parameters of the antioxidative response system, as the superoxide dismutase (SOD) and catalase enzyme activities besides the proline content were evaluated to measure the extension of the saline stress and their effects on the plants. The increase of EC of the soil induced to the increase of the proline concentration and the SOD activity. Unexpectedly, it was verified that the saline stress inhibited the activity of the enzyme catalase. It was also concluded that the monitoring of EC of the soil is an indispensable tool to reach success in the fertigation system and that the study of the activity of the enzymes of the antioxidative response system, and the proline contents can be assumed as indicators in of the levels of stress in bell pepper plants (Capsicum annuиm L.; cv Elisa).

Key words: crop production, enzymes, fertigation, plant stress.

\section{RESUMEN}

La producción en invernadero asociada al manejo de fertirriego se ha establecido en Brasil como una alternativa económica para varias especies hortícolas. Este estudio tuvo como objetivo evaluar posibles impactos en el metabolismo en plantas de pimiento (Capsicum annuum L.; cv Elisa). En respuesta al aumento de la concentración mineral del suelo debido al fertirriego durante los ensayos, fueron alteradas las concentraciones de nutrientes para inducir altos valores de conductividad eléctrica (CE) en la solución del suelo. Valores de CE observados comúnmente en sistemas de fertirriego convencionales fueron tomados como tratamiento control. Se estudió también la posibilidad de la reducción del impacto del estrés mineral mediante la aplicación de materia orgánica en el sustrato del cultivo. Parámetros del sistema de respuesta antioxidativo, como la actividad de las enzimas superóxido dismutasa (SOD), catalasa además de prolina fueron evaluadas para medir el alcance de los efectos del estrés salino y sus efectos metabólicos. El aumento de la CE en la solución del suelo indujo fuertemente la concentración de prolina y la actividad de la enzima SOD. Se observó que el estrés salino causó inhibición de la actividad de las catalasas. En función de los resultados obtenidos, se concluye que el monitoreo de la CE de la solución del suelo es un factor indispensable para tener éxito en las prácticas de la fertirrigación y que el estudio de la actividad enzimática del sistema de respuesta antioxidativo y contenido de prolina pueden asumir un papel importante como indicadores de los niveles de estrés en plantas de pimiento (Capsicum annuum L.; cv Elisa).

Palabras clave: enzimas, producción vegetal, fertirriego, estrés vegetal.

\section{Introduction}

One of the potential risks of the use of the fertigation system is the process of soil salinization, mainly if the soil already contains high contents of soluble salts. In greenhouse production, the soil managements and the irrigation should be carefully planned in order to avoid the salinization (Silva et al., 1999).

\footnotetext{
Agronomic Sciences College, São Paulo State University, Botucatu 18603-970, Brazil.

Institute of Biosciences, São Paulo State University, Botucatu 18618-000, Brazil.

Laboratory of Biochemistry and Plant Physiology, Agronomy College, UTFPR, Pato Branco 85503-390, Brazil.

Centro de Investigación en Química Aplicada (CIQA) - Dep. de Agroplasticultura, C.P. 25294 Santillo, Coahuila México.

* Autor para correspondencia: broetto@ibb.unesp.br
}

Fecha de Recepción: 23 Noviembre, 2011.

Fecha de Aceptación: 2 Septiembre, 2013. 
In saline stress, a rapid reduction in the readiness of water to the plants can happen, in terms of the reduction of the total potential in the soil. The largest or the smallest effort to win the difference of the osmotic potential varies according to the plant species, for adaptation to different salinity conditions (Lima, 1997). The possibility of the increase of the saline potential of the soil is higher in greenhouse production, being considered that, with the fertigation, it is avoided great flotations in the concentration of nutrients in the solution of the soil. This factor can mean a favorable aspect in the productivity, mainly for bell pepper that is considered a culture moderately sensitive to the salinity with an electric conductivity (EC) of $1,5 \mathrm{dS} \mathrm{m}^{-1}$ (Mass and Holfman, 1977; Lorens and Maynard, 1988).

According to Cruciani (1987), under conditions of saline stress, the leaves of bell pepper can present green blued dark coloration, larger thickness and waxy, while the roots present a decrease of the lenght and suberization, what affects the absorption of water and nutrients with consequent decrease of the productivity.

Levitt (1980) classified the injuries in plants due to saline stress in primary and secondary. The direct primary stress involves physiologic damages in membranes, as for instance alterations in the permeability and ion flux. Indirectly, the salinity can interfere in the metabolism of proteins, taking to changes in the enzymatic activity and other metabolic disturbances. The secondary stress is characterized by the simulation of the osmotic stress (water), what brings, as consequences, dehydration, loss of the leaf turgor, inhibition of the growth, and mineral deficiency.

In conditions of water stress, osmotic stress, light, salinity, temperature, damages provoked by pathogens, herbicides and other, there is the formation of ROS. These forms include oxygen as hydrogen peroxide $\left(\mathrm{H}_{2} \mathrm{O}_{2}\right)$, superoxide radical $\left(\mathrm{O}_{2}^{-}\right)$, and the hidroxile radical $\left(\mathrm{OH}^{-}\right)$. This reactive oxigene forms are known by oxidize important cellular constituents, such as nucleic acids, lipid and protein membrane (bipolar layer), which could take the cells to death (Alscher et al.,1997). Some plants developed defense mechanisms against the damages caused by the oxidative stress. Among these mechanisms, it is stood out the increase of the activity of enzymes of the antioxidative metabolism.

Therefore, it is suggested that the plants can be relatively (depending on the species) equipped with an effective system to control the harmful action of the free radicals. In several species of plants it was observed a super expression of the activity of the enzyme superoxide dismutase (SOD; EC 1.15.1.1) and catalases due to several stressing factors (Miszalski et al., 1998; Broetto et al., 2002).

The present study had as aim to evaluate the effects of the saline stress induced on some biochemical parameters in plants of bell pepper.

\section{Material and Methods}

The experiment was carried out in greenhouse, it was used pots with $30 \mathrm{~L}$, containing dystrophic dark red ultisol medium texture $\left(\mathrm{pH}=\mathrm{CaCl}_{2} 4.2\right.$; $\mathrm{OM}=14 \mathrm{~g} \mathrm{dm}^{-3} ; \mathrm{P}=2 \mathrm{mg} \mathrm{dm}^{-3}$ (resin), $\mathrm{K}=0.2$, $\mathrm{Ca}=4$, and $\mathrm{Mg}=1 \mathrm{mmol} \mathrm{dm}^{-3} ; \mathrm{V} \%=6$ ).

Dolomitic limestone was applied to elevate the $\mathrm{V}$ to $80 \%$, and the $\mathrm{P}$ to $150 \mathrm{mg} \mathrm{L}^{-1}$ in the soil (75 mg P was applied as simple superphosphate and $75 \mathrm{mg} \mathrm{P}$ in the termophosphate form containing sulfur and micronutrients). In the treatments where organic matter was used, it was applied $260 \mathrm{~g}$ of dry corral manure by vase, equivalent to $20 \mathrm{tha}^{-1}$. The experiment was set in a entirely randomized design, in factorial outline $4 \times 2$, with 4 replications with 4 fertilizer doses in presence and absence of organic matter.

In the vases of the control treatment, it was applied $0.24 \mathrm{~g}$ plant $^{-1}$ of $\mathrm{N}$, in the form of nitrate of calcium and $0.2 \mathrm{~g}$ plant $^{-1}$ of $\mathrm{K}$ in the form of $\mathrm{KCl}$, parceled out every three days (Villas et al., 2000), the EC of the soil was maintained around $1,5 \mathrm{dS} \mathrm{m}^{-1}$ (Lorens and Maynard, 1988). According the equations of salinization of soil obtained by Leonardo et al. (2012), $\left(\mathrm{EC}=0.053 \mathrm{~g} \mathrm{Ca}\left(\mathrm{NO}_{3}\right)_{2}+\right.$ 0.4029 and $\mathrm{EC}=0.0967 \mathrm{~g} \mathrm{KCl}+0.38$ ), it was applied the amounts of $\mathrm{Ca}\left(\mathrm{NO}_{3}\right)_{2}$ and $\mathrm{KCl}$ to elevate the $\mathrm{EC}$ to $2 \mathrm{X}\left(3.0 \mathrm{dS} \mathrm{m}^{-1}\right), 3 \mathrm{X}\left(4.5 \mathrm{dS} \mathrm{m}^{-1}\right)$ and $4 \mathrm{X}(6.0 \mathrm{dS}$ $\mathrm{m}^{-1}$ ) the values considered as control $\left(1.5 \mathrm{dS} \mathrm{m}^{-1}\right)$. The mentioned fertilizers were applied in solution, through drip system.

The extractor of solution of the soil and the electronic tensiometers were installed to a distance of $15 \mathrm{~cm}$ of the plant and the depth of $20 \mathrm{~cm}$ of the center of the porous capsule. Depending on the behavior of EC of the soil, measured biweekly, the dose of the fertilizers was altered, in agreement with the equation of salinization of soil.

The leaves were collected to the analyses of biochemical parameters. The expanded leaves 
were collected in the medium area of the plants, conditioned in cryogenic vials and immediately immersed in liquid $\mathrm{N}$ for fast freezing and stored in freezer $\left(-80^{\circ} \mathrm{C}\right)$. The samples were processed for obtaining two different extracts: the first one to the analysis of the content of L-proline and the second to the analyses of enzymatic activity. For the first extract, samples of leaf tissue $(100 \mathrm{mg})$ were resuspended in $1.5 \mathrm{~mL}$ of sulfosalicylic acid (3\% in distilled water). After centrifugation for 5 $\min$ at $4,000 \times \mathrm{g}$ the supernatant was collected and stored in freezer $\left(-80^{\circ} \mathrm{C}\right)$.

The extract for the enzymatic analyses was obtained by the suspension of the plant material $(300 \mathrm{mg}$ ) in $5.0 \mathrm{~mL}$ of potassium phosphate buffer (0.1 M, pH 6.8). After centrifugation for 10 minutes at $10,000 \mathrm{x} \mathrm{g}$, the supernatant was collected and stored in freezer $\left(-80^{\circ} \mathrm{C}\right)$. The concentration of soluble protein in the extracts was determined in threefold (Bradford, 1976) with bovine serum albumin (BSA) as protein standard.

The content of L-proline was determined according to Bates et al. (1973) method. The determination of the activity of SOD considered the capacity of the enzyme in inhibiting the photoreduction of NBT (nitroblue tetrazolium chloride) as described by Giannopolitis and Ries (1977). The activity of the catalase was determined by the monitoring of the variation of the absorption of the hydrogen peroxide $(240 \mathrm{~nm})$, according to Peixoto et al. (1999).

\section{Results and Discussion}

With the analyses of the results presented in the Table 1, it can be verified that there was significant variation for all of the treatments with different levels of EC and/or organic matter, except for the analysis of the activity of the catalase enzyme, that was not significant for different levels of EC and for interaction EC x OM (organic matter).

The activity of the enzyme SOD (Figure 1) presented correlation with the increase of EC of the soil. For the control treatment, the activity of the enzyme was about 33,56 , and $71 \%$ smaller, when compared to the treatments 3.0, 4.5, and 6.0 $\mathrm{dS} \mathrm{m}{ }^{-1}$ of EC, respectively.

The SOD enzyme came up to the expectations as biochemical marker of the establishment of typical antioxidative reactions, acting in the dismutation of ROS, common in situation of environmental stress.
Table 1. Variance analysis to the superoxide dismutases (SOD), catalase (CAT) enzyme activity and the proline contents in bell pepper leaves cv. Elisa, in function to different EC levels in the presence and absence of organic matter.

\begin{tabular}{lccc}
\hline Treatments & \multicolumn{1}{c}{ SOD } & \multicolumn{1}{c}{ CAT } & L-Proline \\
\hline Conductivity levels & $0.0001^{*}$ & $0.0679 \mathrm{~ns}$ & $0.0001^{*}$ \\
Organic matter & $0.0157^{*}$ & $0.0412^{*} *$ & $0.0007^{*}$ \\
Interaction (EC x OM) & $0.6844 \mathrm{~ns}$ & $0.2398 \mathrm{~ns}$ & $0.0001^{*}$ \\
C.V. $(\%)$ & 15.09 & 114.83 & 3.16 \\
\hline
\end{tabular}

*significative at $1 \% * *$ significative at $5 \%$ ns not significative.

The application of organic matter was significant, how observed in the Table 1, representing a stimulating factor the activity of the enzyme, however without direct relationship with a expected stress attenuation, due to the increase of EC. The mechanisms that would be forming this interaction were not aim of the study of the experiments.

The performance of the SOD activity in the development of the culture is presented in Figure 2. It was observed that, for all of the applied treatments, there were only few variations, when it was compared the different collecting times. As exception, was verified that to 78 DAT (days after transplant), when the plant enters in a transition period between the vegetative stadium for the reproductive one, the activity of the enzyme decreased. This decrease happened in the end of the cycle again.

The SOD enzyme presents activity increase, whenever the plants are submitted to agressive environment, as salinity, high temperatures, water stress, high light intensity, pathogens or insect attack, and others (Broetto et al., 2002). However, the activity of the enzyme can be requested, even in normal situations, for dismute ROS evoluted to the cell metabolism in the mitochondria and during the light reactions of the photosynthesis.

The results presented in this research suggest that the treatments with increase of EC simulated the effects of the hydric stress, the ones that, except for the control, maintained the activity of SOD in direct correlation with the increase of this factor.

We observe (Figure 2), strong evidences that indicates that the stressing factors due to EC were, in a certain way, lessened at the end of the cycle (after 108 DAT) of the culture (coinciding with the largest nutrient extraction taxes) what it seems to indicate to be this the cause of the smaller activity of SOD in this period, mainly for the plants of the control. 


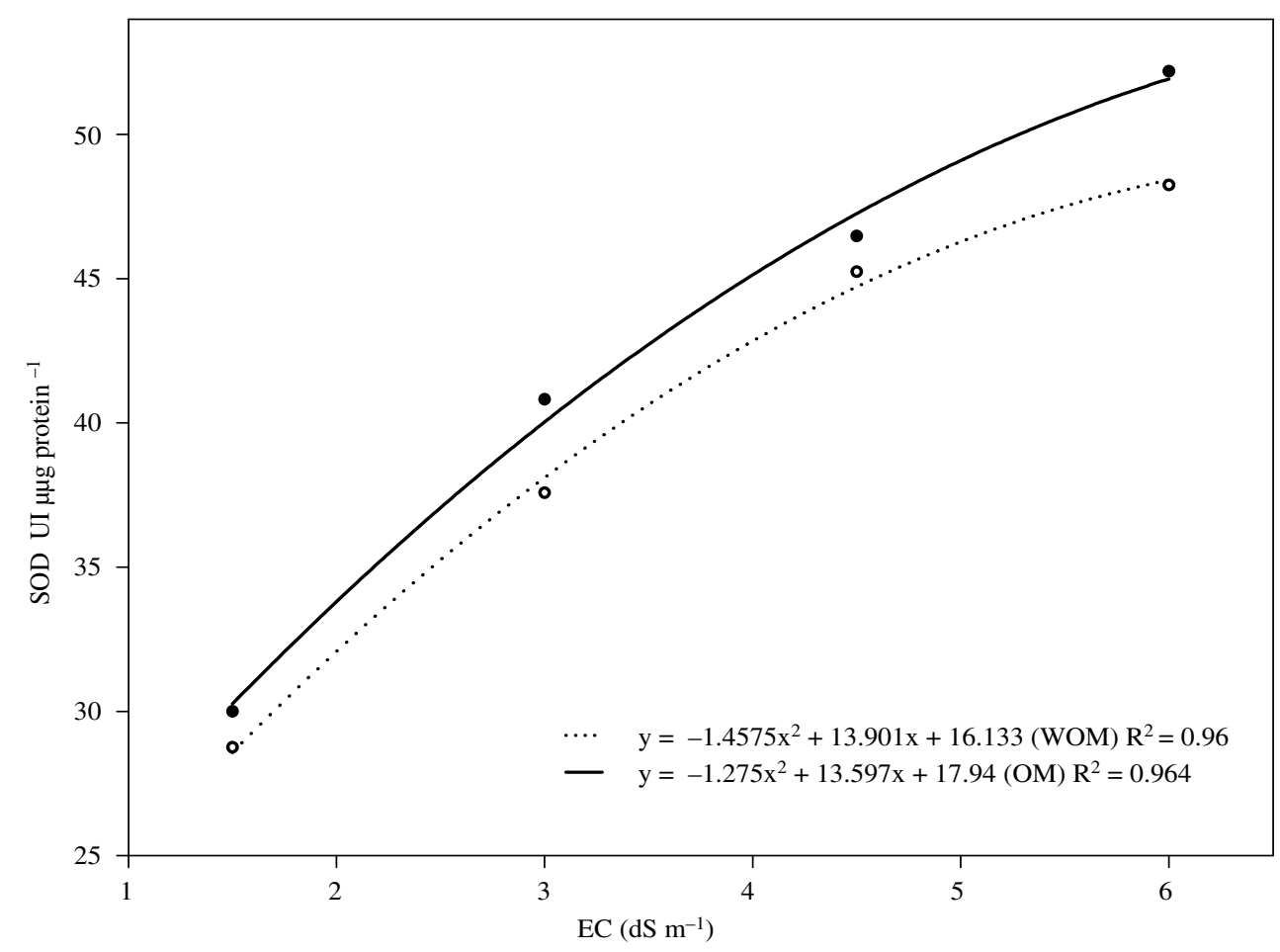

Figure 1. Superoxide dismutases (SOD) activity in response to the salt treatments and supplemented (OM) or not (WOM) with organic matter.

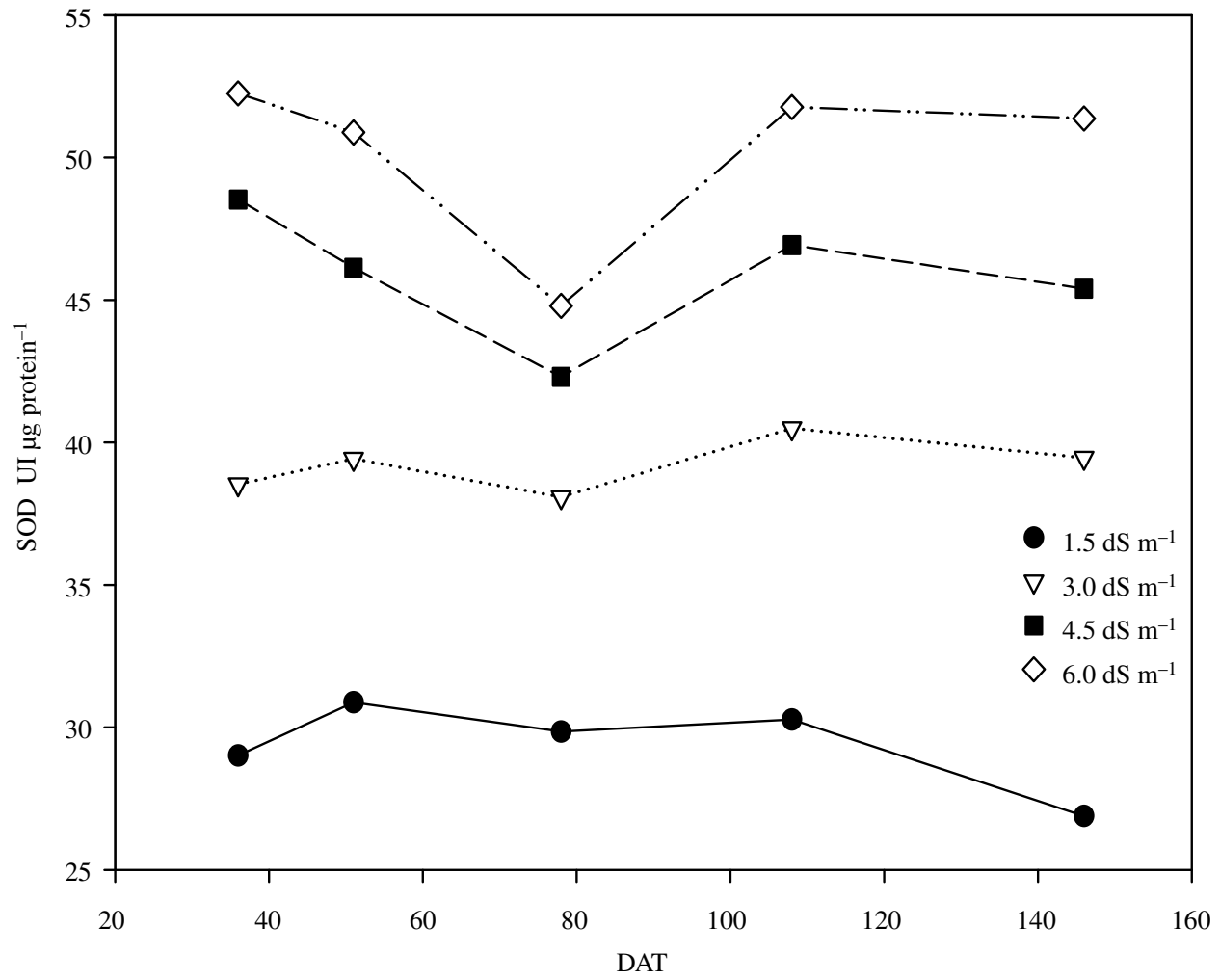

Figure 2. Effect of the different EC regimes on the superoxide dismutases (SOD) enzyme activity during the plant growth. 
The catalase activity (Figure 3) varied little, being considered the different values of EC, until 78 DAT. After this period, and until the end of the cycle of the culture, increase was verified in the activity of the enzyme. This increase can be related with the increase of the taxes of celular respiration, in function of the alteration of the metabolic paths (catabolism) related with the flowering, with emphasis for the control. As these elementary reactions happen in mitochondria level and peroxissomes, it is postulated that the catalase activity has accompanied the events of dismutation of hydrogen peroxide, in cooperation with the enzyme ascorbate peroxidase. This reaction is part of the cycle water-water whose basic reaction of dismutation of free radicals was stirred up by SOD. Therefore, it is assumed that the catalase activity had accompanied the SOD activity, mainly for the most severe treatments. For the catalase, it was observed that the increase of the activity was inversely proportional to the increase of EC of the soil (Figure 4), at the end of the culture. In this case, it is inferred that had happened alteration in the protein structure of the enzyme, due to the stressful effect of the salts causing the decrease of its activity. Such alterations in the catalase activity can happen as answer to the salinity, high light intensities, temperature and other agressive factors, with decrease of its activity (Kalir and PoljakoffMayber, 1981; Broetto et al., 2002). With in vitro experiments it was demonstrated that it's possible to happen effects as alteration of the structure of the enzyme or protein hydrolyze, for the osmotic action of the salt in plant tissues (Feierabend and Engel, 1986).

It was observed that the L-proline content, found in the leaves, increased in response to EC of the soil (Figure 5). In that correlation, the control presented taxes of 40,81 and $92 \%$ smaller than the ones observed in the treatments carried out to $3.0,4.5$, and $6.0 \mathrm{dS} \mathrm{m}{ }^{-1}$, respectively. The supplementation of the soil with organic matter also presented signification in relation to this parameter.

The values presented in Figures 6, demonstrate that there was proline accumulation in the beginning of the experiments. These high contents were decreasing gradually, at the same time that the

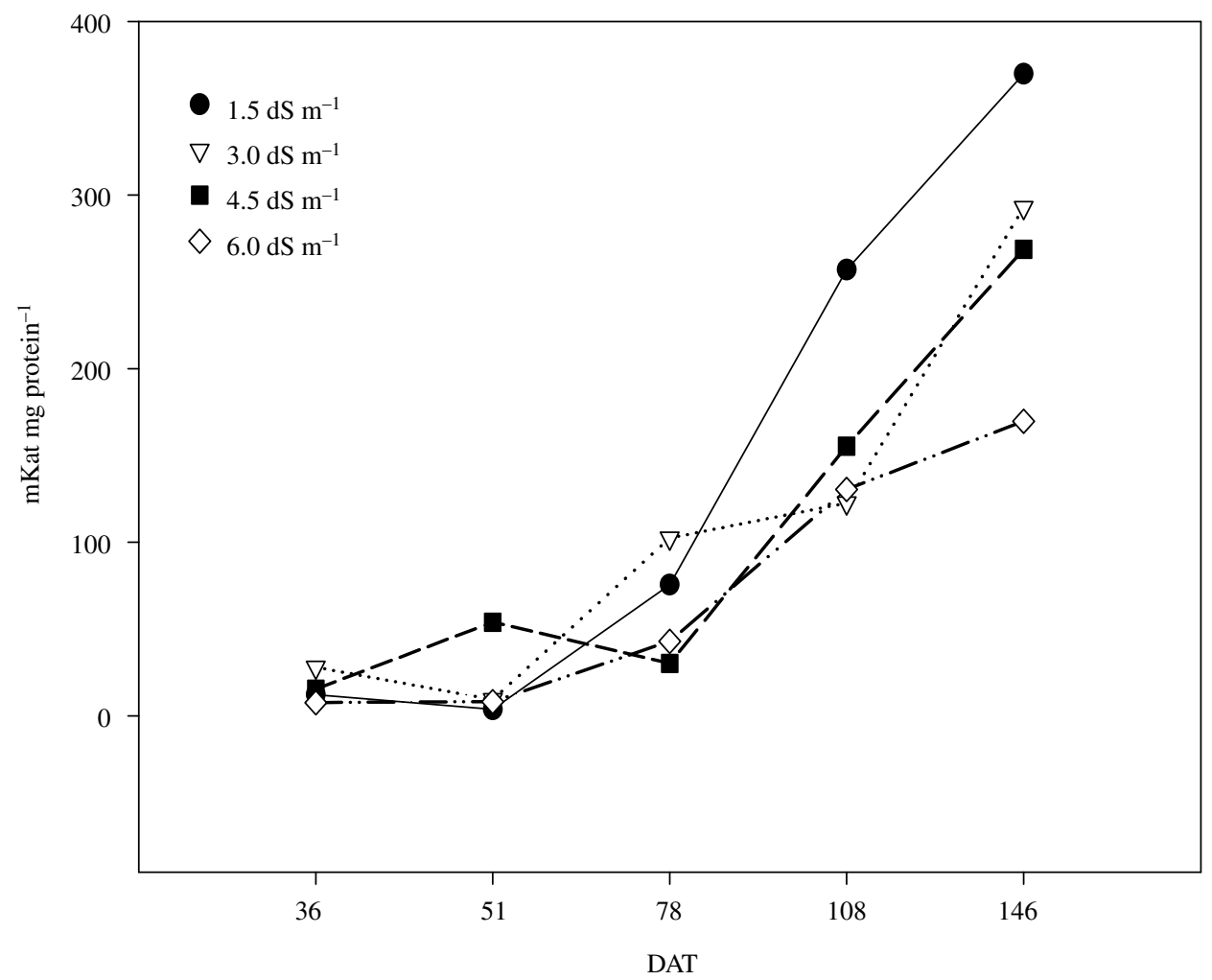

Figure 3. Catalase activity during the plant growth, considerind different EC treatments. 


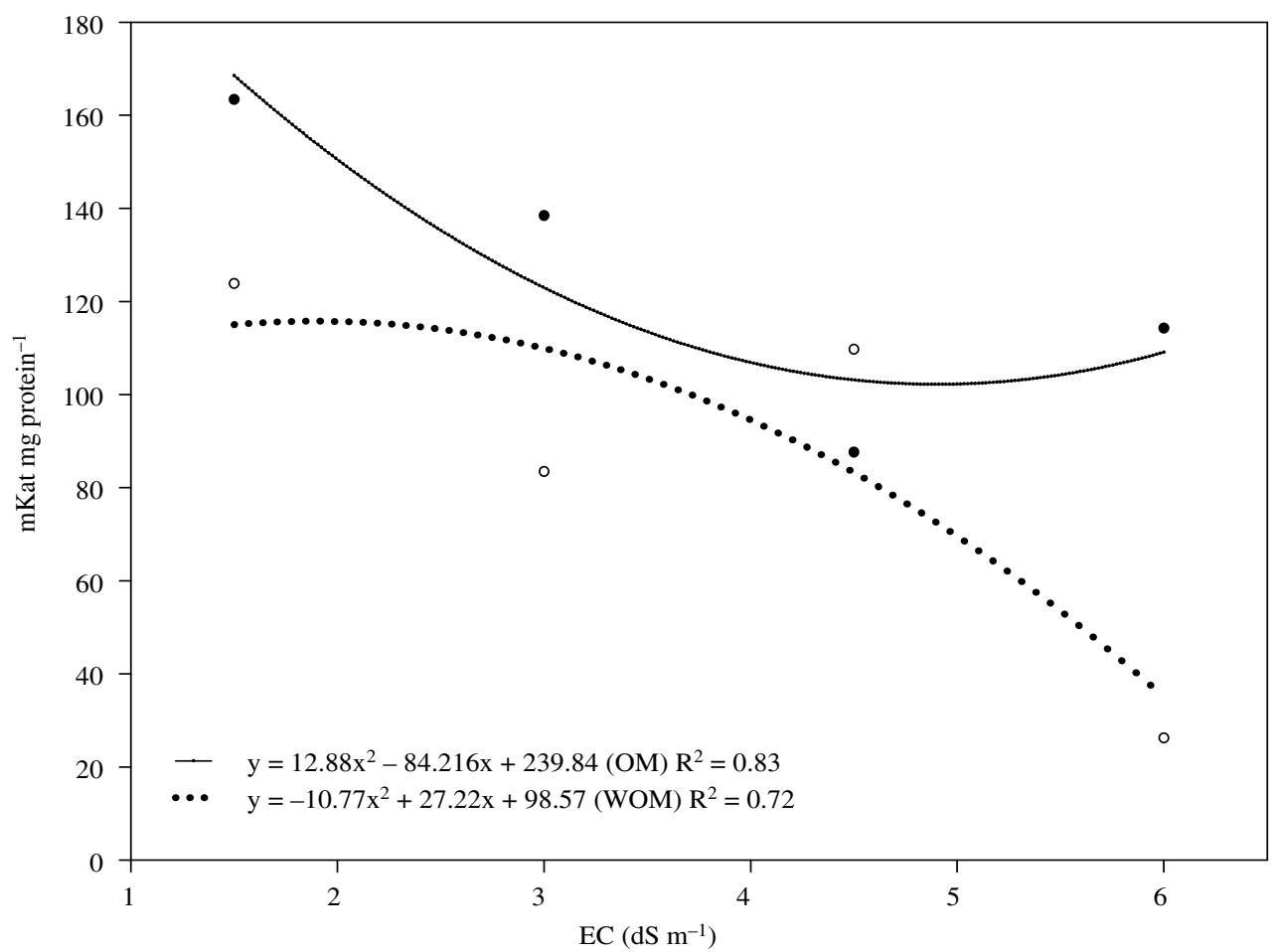

Figure 4. Catalase activity in response to the salt treatments in response to the salt treatments and supplemented (OM) or not (WOM) with organic matter.

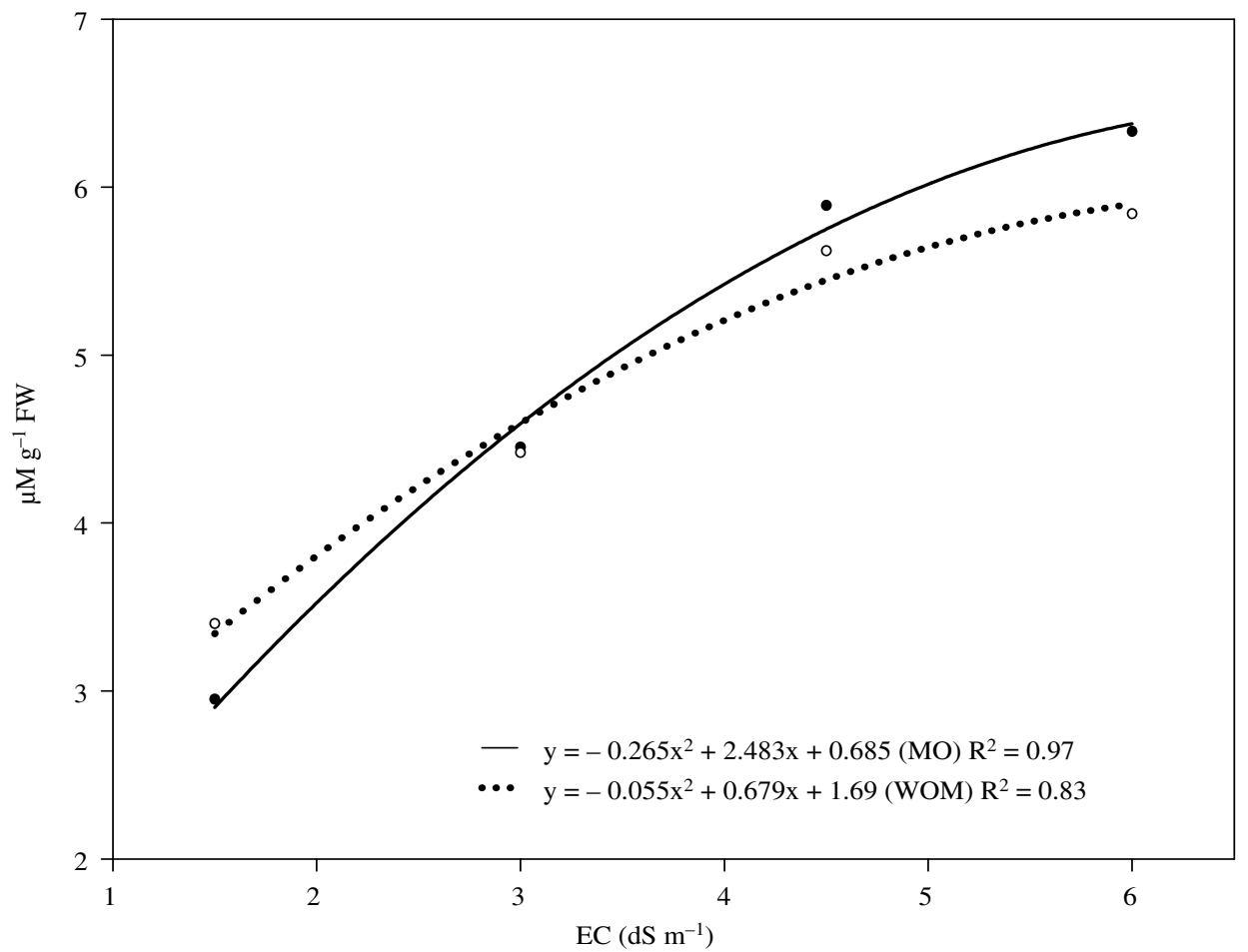

Figure 5. Proline accumulation during de plant cycle due to salt stress in response to the salt treatments and supplemented (OM) or not (WOM) with organic matter. 
culture grew. However, the accumulation of the amino acid always went larger for those treatments with larger EC.

The proline accumulation in plants submitted to saline stress is intensively discussed in the literature, for instance: Jaeger and Priebe (1975); Huber et al. (1977) in bean; Torello and Rice (1986) in grasses; Thomas et al. (1992) in corn in beans calluses. Several authors argue that the proline accumulation happens by the increase of the protein hydrolise in situations of saline stress or as a result of the conversion of sugars in the glycolate pathway.

It's possible, therefore, to discuss the possibility to adopt the proline as amino acid osmoprotector of the proteins (marker) in situations of saline stress, although many authors affirm that this function just has an adaptable value in the conditions of saline stress and not as an indicator of tolerance to the salinity, as mentioned in countless researches (Rodriguez and Heyser, 1988).

Other authors also discuss evidences as for this statement. Torello and Rice (1986) studying the effect of $\mathrm{NaCl}$ in grasses, demonstrated the osmoregulatory effect exercised by the proline accumulation. Weimberg et al. (1984) also verified the correlation between the increases of the tolerance to salts with the proline accumulation in plant tissues.

Little information is found relating to the effect of the salinization of soil, through fertigation, specifically in plants cultivated in greenhouse. As the methodology of proline analysis is relatively simple and of low cost, it can settle down as excellent marker of stressful conditions.

\section{Conclusions}

With the results obtained, it was concluded that the increase of EC of the soil was proportional to the increase of the proline concentration and of the activity of the SOD enzyme and inversely proportional to the increase of the activity of the catalase enzyme.

The monitoring of the activity of the SOD and catalase enzymes of the antioxidative response system and of the proline concentration can be used as indicators of the levels of stress in Capsicum annuum cv Elisa plants.

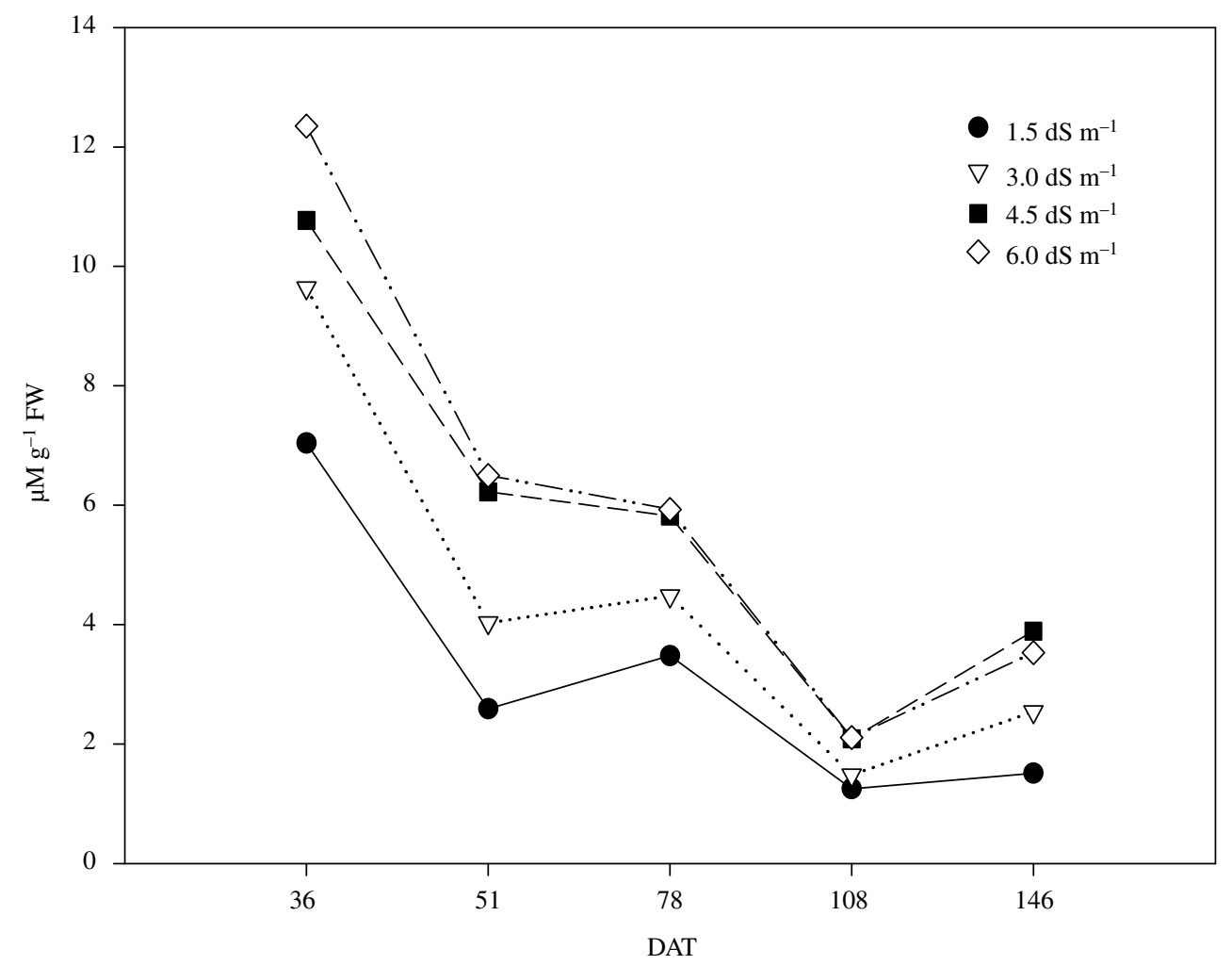

Figure 6. Proline contents during bell pepper growth, submitted to salt stress. 


\section{Literature Cited}

Alscher, R.G.; Donahue, J.L.; Cramer, C.L.

1997. Reactive oxygen species and antioxidants: Relationships in green cells. Physiologia Plantarum, 100: 224-233.

Bates, L.S.; Waldern, R.P.; Teare, I.D.

1973. Rapid determination of free proline for water stress studies. Plant and Soil, 39: 205-07.

Bradford, M.M

1976. A rapid and sensitive method for the quantification of microgram quantities of protein utilizing the principle of protein-dye-binding. Analytical Biochemistry, 72: 248-254.

Broetto, F.; Luttge, U.; Ratajczak, R.

2002. Influence of light intensity and salt treatment on mode of photosynthesis and enzymes of the antioxidative response system of Mesembryanthemum crystallinum. Functional Plant Biology, 29: 13-23.

Cruciani, D.E.

1987. A drenagem na agricultura. 4ed. São Paulo: Nobel, $337 \mathrm{pp}$.

Feierabend, J.; Engel, S.

1986. Photoinactivation of catalase in vitro and in leaves. Archives of Biochemistry and Biophysics, 251: 630-638.

Giannopolitis, C.N.; Ries, S.K.

1977. Superóxido dismutases. I. occurrence in Higher plants. Plant Physiology, 59: 309-314.

Huber, R.K.; Kreutmaier, F.; Sankhla, N.

1977. Eco-physiological studies on Indian arid zone plants: VI. Effect of $\mathrm{NaCl}$ and $\mathrm{ABA}$ on amino-acid and protein metabolism in leaves of Phaseolus acutniifolius. Zeitschrift für Pflanzenphysiologie, 81: 234-247.

Jaeger, H.J.; Priebe, A.

1975. The problem of putrescine formation in plants caused by high salinity. Acta Oecologica, 10: 267-279.

Kalir, A.; Poljakoff-Mayber, A.

1981. Changes in activity of malate dehydrogenase, catalase, peroxidase and superoxido dismutase in leaves of Halimione portulacoides $\mathrm{L}$. aellen exposed to high sodium chloride concentrations. Annals of Botany, 47: 75-85.

Leonardo, M.; Broetto, F.; Marchese, J.A.; Bressan, D.F.;

Marques, D.J.; Coscolin, R.B. dos. S.

2012. Mineral stress and its effects on vegetative development of bell pepper plants cultivated in greenhouse. Genetics and Plant Physiology, 2: 50-56.

Levitt, J.

1980. Responses of plants to environmental stresses. Vol. II. Water, radiation, salt and other stresses. Academic Press New York, pp. 25-211.

Lima, L.A.

1997. Efeitos de sais no solo e na planta. In: Simpósio "Manejo e controle da salinidade na agricultura". Ed .Gheyi; H. R.;
Queiroz, J. E.; Medeiros, J. M. Campina Grande: UFPBSBEA, pp. 113-36.

Lorens, O.A.; Maynard, D.N.

1988. Knott's handbook for vegetables growers. 3ed. John Wiley and Sons, New York, pp. 456.

Mass, E.V.; Holfman, G.J.

1977. Crop salt tolerance - Current assessment. Journal Irrigation and Drainage Division, 103: 115-34.

Miszalski, Z.; Slesak, I.; Niewiadonska, E.; Baczek-Kwinta, R.;

Lüttge, U.; Ratajczak, R.

1998. Subcellular localization and stress response of superoxide dismutase isoforms from leaves in the $\mathrm{C}_{3}$-CAM intermediate halophyte Mesembryanthemum crystallinum L. Plant. Cell and Environment, 21: 169-179.

Peixoto, P.H.P.; Cambraia, J.; Sant'Ana, R.; Mosquim, P.R.; Moreira, A.M.

1999. Aluminum effects on lipid peroxidation and the activities of enzymes of oxidative metabolism in sorghum. Revista Brasileira de Fisiologia Vegetal, 11: (3), 137-43.

Silva, E.F.F.; Duarte, S.N.; Coelho, R.D.

1999. Fertirrigação: "Salinização dos solos cultivados som ambientes protegidos no estado de São Paulo". Agropecuária, pp. 267-278.

Silva, E.F.F.; Duarte, S.N.; Coelho, R.D.

1999. Salinização dos solos cultivados sob ambiente protegidos no Estado de São Paulo. In: Folegatti, M.V. (ed.) Fertirrigação: citrus, flores e hortaliças. Guaíba: Agropecuária, pp. 267-277.

Thomas, J.C.; Armond, R.L.; Bohnert, H.J.

1992. Influence of $\mathrm{NaCl}$ on growth, proline and phospheonolxpyruvate carboxylase levels in Mesembryanthemum crytallinum suspension cultures. Plant Physiology, 98: 626-31.

Torello, W.A.; Rice, L.A.

1986. Effect of $\mathrm{NaCl}$ stress on Proline and cation accumulation in salt sensitive and tolerant turfgrasses. Plant and Soil, 93: 241-27.

Villas, B.R.L.; Kano, C.; Lima, C.P.; Manetti, F.A.; Fernandes, D.M. 2000. Efeito de doses de nitrogênio aplicado de forma convencional através da fertirrigação na cultura do pimentão. In: Congresso Brasileiro de Olericultura. Revista Brasileira de Olericultura, XII - Suplemento, pp. 801-802.

Weimberg, R.; Lerner, H.R.; Poljakoff-Mayber, A.

1984. Changes in Growth and Water-Soluble Solute Concentration in Sorghum-Bicolor Stressed with Sodium and Potassium Salts. Physiologia Plantarum 62: 472-80. 